\title{
Deformation features of the Higher Himalayan Crystallines in Western Bhutan during exhumation
}

\author{
Rodolfo Carosi†, Chiara Montomoli†*, Dario Visonàł \\ † Dipartimento di Scienze della Terra \& Istituto di Geoscienze e Georisorse, via S.Maria 53, 56126 Pisa, ITALY \\ ¥ Dipartimento di Mineralogia e Petrologia \& Istituto di Geoscienze e Georisorse , c.so Garibaldi 37, 35122 Padova, ITALY \\ *To whom corresspondence should be addressed.E-mail: montomoli@dst.unipi.it
}

The superposition of the three main tectonic units building up the core of the Himalayan chain (Lesser Himalaya, Higher Himalayan Crystallines and Tibetan Sedimentary Sequence) have been recognized and mapped also in the Bhutan Himalaya (Gansser 1983, Bhargava 1995, Grujic et al. 1996, 2002, Davidson et al. 1997). Among the main units also the main tectonic discontinuitis, such as the southward thrusting MCT and the northward faulting STDS, have been detected. The HHC, bounded by the nearly coeval MCT and STDS (Hodges et al. 1992), has been interpreted as an extruding wedge (Burchfield et al. 1992, Hodges et al. 1992). Main models regarding the extrusion of the HHC propose a major component of simple shear near the boundaries of the wedge while a pure shear component could accomodate deformation in its central portion (Grasemann et al. 1999, Grujic et al. 2002).

Our work focused in western Bhutan where structural analyses have been performed mainly in the HHC, expecially in its central and upper portion cropping out North of Thimpu. Well developed extensional shear zones have been recognized in gneiss and subordinately in leucogranites. Shear zones strike NE-SW and dip toward the South. Kinematic indicators mainly represented by shear band cleavages and mica fishes point out a top-to-the-SW sense of shear. Microstructural analyses highlight the main metamorphic minerals are deformed by the extensional shear zones while deformation mechanism show ductile up to brittle conditions of deformation. These shear zones could accomodate the pure shear component of deformation expected to be localized in the core of the extruding wedge. Moving upward, at the boundary between HHC and TSS, the extensional deformation of the STDS is localized along a ductile shear zone at the base of the Chekha Formation in the TSS (Grujic et al. 1996). Our meso and microstructural data pointed out some similarities between the lower part of the Checka formation and the North Col formation cropping out in the Everest area and in western Nepal (Carosi et al. 1998).

\section{References}

Bhargava ON.1995. The Bhutan Himalaya: a geological account. Geol. Survey of India, special publ, $245 \mathrm{p}$

Burchfield BC, Z Chen, KV Hodges, Y Liu, L Royden, C Deng and J Xu. 1992 The South Tibetan Detachment system, Himalayan Orogen. Extension contemporaneous with and parallel to shortening in a collisional mountain belt. Geological Society of America, Special paper 269: 1-41

Carosi R, B Lombardo, G Molli, G Musumeci and PC Pertusati. 1988. The South Tibetan Detachment system in the Rongbuck valley, Everest region. Deformation features and geological implications. JAsian Earth Sci 16: 299-311

Davidson C, D Grujic, LH Hollister and S Schmid. 1997. Metamorphic reactions related to decompression and synkinematic intrusion of leucogranite, Hih Himalayan Crystallines. Bhutan.J Met Geol 15: 593612

Gansser A. 1983. Geology of the Bhutan Himalaya. BirkhauserVerlag, Basel. $181 p$

Graseman B, H Fritz and JC Vannay. 1999. Quantitative kinematic flow analyses from the Main Central Thrust Zone (NW Himalaya, India): implications for a deceleratimg strain path and the extrusion of orogenic wedges. J Struct Geol 21: 837-853

Gruijc D, M Casey, C Davidson, LS Hollister, R Kundig, T Pavlis and S Schmid. 1996. Ductile extrusion of the Higher Himalayan Crystalline in Bhutan: evidence from quartz microfabrics. Tectonophysics 260: 2143

Gruijc D, LS Hollister, R Parrish.2002. Himalayanmetamorphic sequence as an orogenic channel: insight from Bhutan. Earth and Planet Sci Letters 198: 177-191

Hodges KV, BC Burchfiel, LH Royden, Z Chen and Y Liu. 1992. The metamorphic signature of contemporaneous extension and shortening in the central Himalayan orogen: data from the Nyalam transect, southern Tibet. J Metamorphic Geol 11: 721-737 